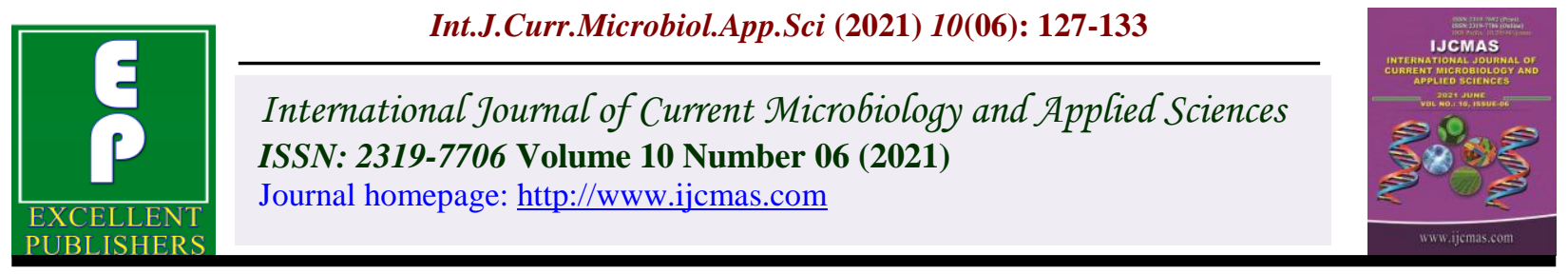

Review Article

https://doi.org/10.20546/ijcmas.2021.1006.013

\title{
Effects of Fertigation on Pineapple: A Review
}

\author{
Kiran Patnaik* and S. N. Dash \\ Department of Fruit Science and Horticulture Technology, O.U.A.T, Bhubaneswar, India \\ *Corresponding author
}

Keywords

leaf margin, spiral arrangement, tropical fruit, short internodes

Article Info

Accepted:

12 May 2021

Available Online:

10 June 2021
Pineapple is a popular and one of the commercially important fruit crop in India. Increasing the productivity of pineapple in India is still a constraint, even after enjoying conducive agro-climatic conditions in many growing belts of the country. Pineapple growers in India, mostly cultivate pineapple as a rain-fed crop providing low input supply due to its hardy nature of growth. Fertigation has a great potential for the efficient use of water and fertilisers. Its application has shown promising results in many fruit crops. It provides an enormous possibility of tailoring nutrient use across the critical growth stages of pineapple crop. Application of fertigation in pineapple carries a vast potential in future. A very limited study on the effects of fertigation has been done in pineapple crop which has been addressed in this review.

\section{Introduction}

Pineapple (Ananas comosus (L.) Merr.) is an important tropical fruit having a great demand in the international market with an annual world production of 28.3 million metric tons of fruits (FAOSTAT, 2018).

India is the fifth largest producer of pineapple with an annual production of 1706 thousand MT from 103 thousand hectare area in 201718 (NHB data, 2017-18). It is consumed mainly as a fresh fruit and a wide range of processed products are also prepared out of it. Pineapple has many xerophytic adaptations like wax coated fleshy erect leaves with sunken stomata, spines on the leaf margin, and spiral arrangement of the leaves at short internodes to a club shaped dwarf stem giving a rosette appearance to the plant. Its roots can spread up to $1-2 \mathrm{~m}$ laterally and $85 \mathrm{~cm}$ in depth. Pineapple is an obligate Crassulacean acid metabolism (CAM) plant which stores carbon dioxide and fixes it as malic acid at night when stomata open. This mechanism increases the efficiency of photosynthesis which prevents excessive water loss due to transpiration from open stomata during day time. Pineapple has a lower water requirement than the vast majority of cultivated fruit 
plants. Though it is a hardy crop and mainly grown in rain-fed conditions, it requires water and nutrient supply during establishment stage and flowering period.

The nutritional status of the pineapple plants plays a major role on influencing the plant growth, production and fruit quality. Pineapple is a shallow feeder with high $\mathrm{N}$ and $\mathrm{K}$ requirement. Since these nutrients are prone to heavy losses in soils, practices relating to time of application and form of fertilizer determine their efficient use. Many studies on nutritional requirement have suggested that a dose of $\mathrm{N}, \mathrm{P}_{2} \mathrm{O}_{5}$ and $\mathrm{K}_{2} \mathrm{O}$ at 12,4 and 12 $\mathrm{g} /$ plant/year respectively is optimum under Indian conditions. The use of balanced fertilization at appropriate time and of proper quantity plays a vital role in enhancing the productivity of crop. Though, being a popular tropical fruit throughout the world, not many studies have been done on its nutrient management especially through microirrigation.

In India, fertigation practice is of recent interest, though this technology has been in use in many developed countries especially in Israel and USA. In most of the developed countries fertigation has become a standard practice for fertilizer application. Limited works have been done in India in high value crops, short duration crops or crops grown under protected cultivation. The favourable results from the studies done on fertigation have indicated immense potential for practicing this technology throughout the country.

Fertigation is the use of combination of drip irrigation and fertiliser to create a controlled nutrient release system. Irrigation and fertilisers are the most important inputs which directly affect the plant growth, development, yield and quality of produce. Application of required nutrients through fertigation can reduce the nutrient loss and increase the nutrient use efficiency since it reduces surface evaporation, surface runoff and deep percolation of applied water (Jiusheng et al., 2003). In regions where water and labour are precious resources, fertigation can be a boon for the crop production. Fertigation can save water, nutrients and labour involved in managing these resources and make farming a profitable venture in long run.

Studies on edible pineapple suggest that localised drip irrigation and quantifying the water depth using climate parameters are strategies that can help reduce water wastage and increase production potential. Pineapple irrigation and nutrient management are often neglected since it is a hardy fruit crop, cultivated as a rain-fed crop. It has a long vegetative phase of growth extending up to 10-12 months. It is the most important phase of growth in crop cycle of pineapple as the plant vigour and yield potential can be assessed by the growth during the vegetative stage. Suckers, the commonly used planting material will take 3-4 months to establish a good root system. Application of phosphates fertilizers at the time of planting of pineapple suckers as basal dose helps to develop root system and faster establishment. Nitrogen and potassium are required in early growth stages and flowering time. Application of high dose of nutrients at the time of fruit development will reduce the fruit quality. Plant growth characteristics, especially, the D leaf parameters like D leaf length, D leaf width, D leaf weight and thickness at the time of flower induction can influence the production potential of the crop.

In pineapple through fertigation, application of fertiliser in small doses can be given in the entire growing season which can match the crop nutrient requirements and eventually maximize the returns per unit amount of fertiliser. The nutrient leaching loss is 
efficiently minimised in fertigation, which can prove more advantageous for a crop having shallow root system like pineapple. Fertigation through drip system provides water and nutrients to an area of soil where most of the roots are present. Pineapple crop is closely spaced and due to it spiny leaves, performing intercultural operations including fertilization becomes difficult which can be eased by spreading drip lines between the plots of pineapple crop.

García et al., (2017) reported that restrictions on soil fertility, affect the yield and quality of pineapple fruits. Thus, the use of fertigation, might be beneficial for pineapple producers as this system enables precise applications of fertilizers at the moment of plants higher demand, which enables greater yield and better fruit quality.

\section{Effect of fertigation on pineapple growth and yield}

Precise application of water and nutrients enhances growth and improves the yield by increasing the fruit size and weight. Bonomo et al., (2020) evaluated the yield and quality of 'Pérola' pineapple under increasing rates of nitrogen and potassium applied through fertigation. Increasing nitrogen rates provided linear growth on fruit production features and the rate of $516 \mathrm{~kg}$ ha- 1 resulted in fruits with the largest diameters. The highest total yield on 'Pérola' pineapple crop was reached on plants under the supply of $498 \mathrm{~kg}$ ha- 1 of $\mathrm{K}_{2} \mathrm{O}$.

Rates between 523 and $583 \mathrm{~kg}$ ha- 1 of $\mathrm{K}_{2} \mathrm{O}$, provided the largest fruit matter and the highest fruit pulp yield. The increasing amount of nitrogen applied by fertigation resulted in linear growth on fruit pulp $\mathrm{pH}$, though it did not influence the soluble solids content. The lower acid content and higher $\mathrm{SS} /$ acid ratio on fruits were reached with the $\mathrm{N}$ rates of 333 and $375 \mathrm{~kg}$ ha-1 respectively.
Maneesha et al., (2019) studied the effect of fertigation levels on the vegetative growth of pineapple variety 'Giant Kew' during the crop establishment stage and the flower induction stage of the plant crop. At crop establishment stage, the highest plant height $(58.24 \mathrm{~cm})$ and stem girth $(36.33 \mathrm{~cm})$ were recorded in T2 (Drip fertigation with 125\% RDN i.e.15: 5:15 g NPK/ plant/ cycle) treatment. The number of leaves were high in T2 (17.46) and T3 (17.82) treatments. The plants under T2 and T3 (Drip fertigation with $100 \%$ RDN i.e. 12:4:12 g NPK/ plant/ cycle) also had the highest D leaf length $(63.47 \mathrm{~cm}, 85.09 \mathrm{~cm}$ respectively), D leaf width $(3.59 \mathrm{~cm}$ and $3.57 \mathrm{~cm}$ respectively) and D leaf thickness. D leaf weight was highest in T2 treatment (42.39 g). At flower induction stage, T2(Drip fertigation with 125\% RDN i.e.15: 5:15 g NPK/ plant/ cycle) had the highest plant height $(85.03 \mathrm{~cm})$, Number of leaves (48.91) and stem girth $(41.88 \mathrm{~cm})$ which was on par with T3 and T4. $\mathrm{D}$ leaf length, $\mathrm{D}$ leaf weight and $\mathrm{D}$ leaf thickness were also high in T2 treatment. Chlorophyll a, chlorophyll $\mathrm{b}$ and total chlorophyll content and chlorophyll $\mathrm{a} / \mathrm{b}$ ratio was the highest in $\mathrm{T} 2$, but there was no significant difference between the treatments.

Drip fertigation can be effective in pineapple especially during the initial month of crop establishment when the plant need consistent low volume supply of water for developing root system. Efficient application of fertigation also depends on frequency of fertigation applied to the crop in its growing period or critical stages of water requirement. According to Silber (2005), frequent fertigation improves the uptake of nutrients through two main mechanisms: continuous replenishment of nutrients in the depletion zone in the vicinity of the root-soil interface; and enhanced transport of dissolved nutrients, because of the increased average water content in the medium. Ribeiro et al., (2019) studied the effect of nitrogen $(\mathrm{N})$ and potassium $(\mathrm{K})$ 
fertigation frequencies on the physicalchemical fruit characteristics of 'Pérola' pineapple crop. $\mathrm{He}$ observed that the $\mathrm{N}$ fertigation frequencies had no effect on variables evaluated but the $\mathrm{K}$ frequencies had a significant influence on fruit mass with crown, yield and $\mathrm{pH}$. The results showed that the effect of $\mathrm{K}$ frequencies applied through fertigation on pineapple yield and fruit physical-chemical quality was more pronounced in comparison to the effect of $\mathrm{N}$ applications. Monthly potassium fertigations, followed by four applications throughout the crop cycle, provided the greatest increase in fruit quality, allowing higher values of fruit mass, yield and $\mathrm{pH}$.

Acevedo et al., (2017) conducted an experiment to study the effects of fertilizer application methods and drip irrigation management on pineapple yields. Pineapple cultivars MD-2 and Cabezona were planted at Isabela and Lajas, Puerto Rico, respectively. Fertilizer and irrigation treatments included: i) Control application of $896 \mathrm{~kg} / \mathrm{ha}$ of a granular fertilizer (12-6-10-3) at two, five and nine months after planting; ii) FS-R- application of $150-150-120-45 \mathrm{~kg} / \mathrm{ha}$ at planting plus 20 foliar applications of urea and potassium sulfate $(50 \mathrm{~kg} / \mathrm{ha})$ every three weeks, rainfed; iii) FS-DI- application of 150-150-120-45 $\mathrm{kg} / \mathrm{ha}$ at planting plus 20 foliar applications of urea and potassium sulfate $(50 \mathrm{~kg} / \mathrm{ha})$, drip irrigation applied every three weeks; iv) FERT- application of $150-150-120-45 \mathrm{~kg} / \mathrm{ha}$ at planting, but urea and potassium sulfate (50 $\mathrm{kg} / \mathrm{ha}$ ) were applied throughout fertigation; and v) CRF- same amount of nutrients as FS$\mathrm{R}$ but $\mathrm{N}$ was applied as a controlled release fertilizer every six months. At Isabela, treatment FS-R produced the highest fruit weight $(2.5 \mathrm{~kg}$ per fruit) and $1.5 \%$ of $\mathrm{N}$ in tissue, but did not differ significantly from FSDI and CRF. Plants under CRF registered the highest Brix $\left(15.8^{\circ}\right)$. Although foliar fertilizer tended to produce higher yields, controlled release fertilizer is recommended because it eliminates the need for frequent foliar application without compromising yield.

Paoli et al.,(2010) tested the response of pineapple plants to fertilization and drip irrigation. The fertilization treatments applied were 1) Granular fertilizer at a rate of 150$150-120-45 \mathrm{~kg} / \mathrm{ha}$ at planting plus 16 foliar applications of $\mathrm{N}$ and $\mathrm{K}$ at rate of $50 \mathrm{~kg} / \mathrm{ha}$ every two weeks. 2) Same as treatment 1 but with the addition of drip irrigation. 3) Same as treatment 1 applied twice monthly throughout fertigation. 4) Fifty per cent than treatment 1 through fertigation. Pineapple harvesting was done 18 months after planting. Neither conventional fertilization (granular) nor fertigation treatments affected fruit weight. There was a tendency of sweeter $(B r i x=14.08)$ and heavier fruits $(1.3 \mathrm{~kg} /$ fruit $)$ with plants submitted to conventional fertilization with drip irrigation (treatment 2). Pineapple plants under drip irrigation produced heavier fruits and taller plants than rain fed plants. The results indicated that drip irrigation and fertigation is an alternative management practice for cultivar 'M-D-2 Del Monte' at northern Puerto Rico.

Among the various factors that limit the productivity of pineapple water stress, nutrient deficiency and competition of weeds are important. Weeds cause massive reduction in yield as pineapple crop is slow and it has very slow vegetative development. Weeds poses a major problem in pineapple cultivation as weeding is difficult due to spiny leaves of pineapple. Fertigation along with mulching promotes spot irrigation and nutrient management to the root zone of crop which eventually suppresses the weed growth by restricting its moisture and nutrient supply. According to Reinhardt (2002) and Catunda et al., (2005), pineapple has slow growth and superficial root system which expose it to intense competition with weeds, and 
contribute to delay crop development and reduce their yield and quality. That is why, it is recommended to keep the fields clean from weeds during the first five to six months of planting.

Drip fertigation in combination with plastic film mulch is one of the best management options which can improve the water management while controlling the weed growth in the crop. Mulching improves soil water retention, reduce soil temperature, soil erosion, and reduce wind velocity at the soil surface. The temperature of the soil surface covered by the mulch film is about $2-3^{\circ} \mathrm{C}$ higher than that of the open field which can promote the early emergence and early development of flower in pineapple. Apart from soil moisture conservation by reducing surface evaporation and maintaining soil temperature mulching improves the physical properties of soil. The soil covered by the mulch is looser and more permeable than the uncovered one. After rainfall it can prevent soil compaction and improve soil physical and chemical properties.

Alwis and Herath (2012) studied on the impact of mulching on soil moisture and pineapple growth and yield in which the highest fruit yield of 24.3t/ha was recorded in black polythene treatment which was significantly higher than the poultry litter, coconut husk, paddy husk and rice straw treatments. Similar trend was followed both in plant crop as well as ratoon crop.

Ewere et al., 2017 investigated the effects of six mulch materials and two controls of nonmulched treatments (manually weeded and diuron-applied plots)in a pineapple field in Akure, South-west Nigeria. He found that all mulch materials (cassava peels, Gliricidia sepium leaves, Leucaena leucocephala leaves, Oil palm bunch waste, polythene sheet and wood shavings) significantly increased soil $\mathrm{pH}$. Oil palm bunch waste and wood shavings however increased organic matter and nitrogen content while polythene sheet and wood shaving significantly increased exchangeable acidity. Plot mulched with polythene sheet gave the highest mean temperature of $29.18^{\circ} \mathrm{C}$, soil moisture content of $14.19 \%$ and the lowest weed count and biomass of 5.39 and $5.39 \mathrm{~g}$ respectively. Furthermore, polythene sheet significantly suppressed weeds than other treatments and control.

Garcia et al., 2005 found that plastic mulching resulted in significantly better results than no plastic mulching for: fruit weight (1.9 vs. $1.8 \mathrm{~kg})$, fruit plus crown weight $(2.2 \mathrm{vs} .21 \mathrm{~kg})$, Brix degrees (11.1 vs. 10.8), lower acidity (0.345 vs 0.329$)$ and fruit equatorial diameter (12.7 vs. $12.5 \mathrm{~cm})$.

\section{Cost economics of fertigation in pineapple}

Fertigation reduces the labour cost involved in maintenance of crop. The initial investment in installing a fertigation and micro-irrigation unit is costlier but once established, it reduces the labour cost involved. The high initial investment cost for the system is one of the major constraint but considering it benefits in water saving, increased crop productivity and higher returns, it can be more economicallyviable.

Maneesha et al., (2019) studied the economics of drip fertigation and flower induction in pineapple variety 'Giant Kew' in Goa state. The establishment cost of drip was calculated and a depreciation of $4 \%, 10 \%$ interest on cost and $2 \%$ repair and maintenance cost were considered for the calculation of the fixed costs and operating costs.

The total cost of cultivation was estimated by adding the fixed costs and operating costs along with the main plot and subplot treatment costs. The highest total cost of cultivation of ₹ 421295.05 was recorded in F2T2 followed 
by F2T1 (₹ 420860.04). The net returns were calculated by deducting the total cost of cultivation from the gross returns. Among all the treatments, the net returns were the highest in F2T1 (₹ 1383500.47) followed by F3T1 (₹ 1396412.28). The highest B: C ratio of 3.34 was obtained in F3T1 followed by F2T1 (3.32). Fertigation with $100 \%$ or $75 \%$ RDN by straight fertilizers and flower induction by Ethephon 25ppm+ Urea (2\%) + Sodium carbonate $(0.04 \%)$ can give maximum returns in 'Giant Kew' pineapple production in Goa.

\section{Constraints of fertigation}

Although fertigtion is having lots of advantages, but in a developing country like India, its adoption is still in progress because of few constraints of the technology.

The irrigation system, quality of water, solubility of fertilizers and compatibility of fertilizers are some of the important factors affecting fertigation. The most important criteria for the suitability of an irrigation system for fertigation is accuracy of water application which largely depends upon proper designing, installation of drip system and availability of correct equipment for injecting fertilizers. All these things require skilled labours to operate the fertigation system. Moreover uneven nutrient distribution occurs when the irrigation system is faulty. It leads to over-fertilization or leaching of nutrients when excess water is applied to crops.

Only liquid formulations or water soluble fertilizers can be used for fertigation which are bit expensive than the conventional fertilizers

Chemical reactions of fertilizers with calcium, magnesium and bicarbonates in water can lead to chemical clogging.
Lack of investment due to high cost of equipments of fertigation is also a problem for average Indian farmers.

Lack of information, skill and expertise on plant nutrition and management of fertigation system among pineapple growers.

Increasing water scarcity and escalating fertilizer prices may lead to greater adoption of fertigation in pineapple like other high value fruit crops. Instead of neglecting the irrigation and nutrient demands of pineapple, application of precision farming components especially fertigation and mulching can prove promising results. India is a haven of many indigenous varieties of Pineapple including the cultivated species of the crop. Future research studies on various technology for improving its production can open new gates for lucrative income of country's pineapple growers.

\section{References}

Acevedo M, Román-Paoli E, Román-Pérez $\mathrm{F}$ M, Valencia E, \& Tirado-Corbalá R. 2017. Pineapple growth and yield response to fertilizer and drip irrigation management. The Journal of Agriculture of the University of Puerto Rico, 101(2): 203-223.

Alwis, A. J. and Herath, H. 2012. Impact of mulching on soil moisture, plant growth and yield of Mauritius pineapple (Ananascomosus. L., Merr). Journal of Food and Agriculture. 2(1):15-21.

Ana Maria Alves de Souza Ribeiro, Robson Bonomo, Moises Zucoloto, Fábio Oseias dos Reis da Silva, Mariana Vasconcelos Barroca, Alan de Lima Nascimento, Augusto Moreira de Paula Magalhães, Alex Campanharo, Gleison Oliosi \& Lucas Dalmolin Ciarnoschi. 2019. Potassium and 
Nitrogen Fertigation Frequency on Pineapple Yield and Fruit Quality. Journal of Agricultural Science; 11 (6) Catunda M G, Freitas S P, Viçosa M G, Oliveira J G and Silva C M M. 2005. Efeitos de herbicidas na atividade fotossintética e no crescimento de abacaxi (Ananas comossus). Planta daninha. 23:115-121. 2005.

Elvin Román Paoli, Félix Román Pérez and José Zamora Echevarría. 2010. Increasing pineapple productivity with improved management practices. 46th Annual Meeting Caribbean Food Crops Society.

Ewere C. O, Iseghohi I. O and Gold E. J. 2017. Effects of different mulch materials on soil properties, weed control, growth and yield of pineapple in Akure, Nigeria. Fuoye Journal of Agriculture and Human Ecology. 1(2): 62-74.

García, S S, D J P López, J Z Cruz, CFO. García, L C L Espinoza, M C Estrada, A G Peña, A I O Cebalhos and S C Sánchez. 2017. Integrated system for recommending fertilization rates in pineapple (Ananas comosus (L.) Merr.) crop. Acta Agron. 66: 566-573.

Jiusheng L, Jianjun Z and Ren L (2003). Water and nitrogen distribution as affected by fertigation of ammonium nitrate from a point source. Irrigation Science. 22, 19-30.

Maneesha S R, S Priya Devi, R M Vijayakumar and K Soorianathasundaram. 2019. Effect of fertigation on vegetative growth of pineapple (Ananas comosus (L.)Merr.) Variety 'Giant Kew'. International
Journal of Chemical Studies. 7(3):2832.

Pérez, P. G., García, M. P. G., Rebolledo, L. M., Uriza, D. A., Tinoco, A. A. C. and Rebolledo, A. M. (2005). Planting densities and plastic mulching for "smooth cayenne" pineapple grown in an $\mathrm{aw}_{2}$ climate fluvisol soil in Veracruz, Mexico. Acta Horticulture. 666, 271-275.

Reinhardt D H, Cabral J R S, Souza L F S, Sanches N F, Matos A P. 2002. Pérola and Smooth Cayene pineapple cultivars in the state of Bahia, Brazil:growth, flowering, pests and diseases, yield and fruit quality aspects. Fruits.57:43-53.

Robson Bonomo, Moises Zucoloto, Joabe Martins de Souza, Augusto Moreira de Paula Magalhães, Pedro Henrique de Souza Baldotto, Alex Campanharo. 2020. Production and quality of 'Pérola' pineapple under fertigation. Emirates Journal of Food and Agriculture. 32(2): 109-116.

Silber Avner. (2005). Fertigation frequency and nutrient uptake by plants: Benefits and constraints. Proceedings No. 571, International Fertiliser Society.

SR Maneesha, Priya Devi Shunmuganantham, Vijayakumar R $\mathrm{M}$ and Soorianathasundaram K. 2019. Cost Benefit Analysis of Drip Fertigation and Flower Induction in Pineapple (Ananas comosus L. Merr.) Variety 'Giant Kew' in Goa, India. International Journal of Current Microbiology and Applied Sciences. 8(4): 2010-2019.

\section{How to cite this article:}

Kiran Patnaik and Dash, S. N. 2021. Effects of Fertigation on Pineapple: A Review. Int.J.Curr.Microbiol.App.Sci. 10(06): 127-133. doi: https://doi.org/10.20546/ijcmas.2021.1006.013 